\title{
Assessing the Readiness Level of Don Honorio Ventura State University- College of Computing Studies towards the Implementation of Blended Learning
}

\author{
Aileen P. de Leon ${ }^{1}$, Eden D Garcia ${ }^{2}$ \\ ${ }^{1}$ Don Honorio Ventura State Univerisity, Philippines \\ 2 College of Computing Studies, Don Honorio Ventura State University, Philippines
}

\begin{abstract}
The study focused on the rationale use of technology that is widely spreading around the world. Educational technology is significant in the learning and teaching process. The significance of the developed game-based courseware was to provide instruction and self-drill-and-practice to understand the computer system servicing terms and concepts. This interactive courseware is an additional innovation that will significantly help in the learning and teaching process. The conceptual framework of the study used to organize and varied literature which establishes the scope of education and principles of game-based courseware. The researcher utilized a questionnaire as the primary research instrument. The weighted mean and the standard deviation are used to determine the acceptability of the courseware. To adopt the opportunities offered by developed game-based courseware, it is essential to focus on lessons learned in Computer System Servicing. Features such as peer to peer learning and camaraderie between learners and educators have been found significant in traditional lessons and converted to educational games, as modern technologies move into the informative mainstream. Additional research into the effects and development of gamebased approach courseware to classify the role of teachers as facilitators in the game-based approach of learning can establish ways to develop and create educational practices that better engage and motivate students.
\end{abstract}

Keywords: Courseware, game-based learning, educational technology, CSS

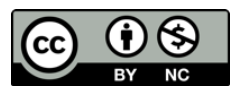

This is an open access article under the CC-BY-NC license

\section{INTRODUCTION}

Today, the use of technology is widely spreading around the world. It has become an integral part of our daily live in every aspect of human life including our communication, selfexpression, and even our very own sense of humanity. Computer games meet the actual needs and interests of children and are becoming the most popular computer activity and provide a new mode of interaction. Some of the advantages of games are that they are attractive, novel, provide a better atmosphere and help keep the learner focused on the task (Heinich, Molenda, Russell, \& Smaldino, 2002), therefore suggesting games as valuable educational tools. Kids like all humans love to learn when it is not forced upon them. Modern computer and video games provide learning opportunities every second or fraction thereof Prensky, (2003) and Gee (2003) argues that "the real importance of good computer and video games is that they allow people to recreate themselves in new worlds and achieve recreation and deep learning at the same time". Some educators consider game-based

Corresponding author apdeleon@dhvsu.edu.ph DOI: doi.org/10.31098/issues. v1i1.611 
learning to be a powerful instructional approach (Von Wangenheim \& Shull, 2009). The educational game makes the learner become the center of learning, which allows the learning process to be easier, more interesting, and more effective.

The $\mathrm{K}-12$ curriculum is designed to develop a lifelong learner who engages in critical thinking and creative problem-solving. Moreover, game-based learning promotes the 21st-century skills, particularly 4c's: communication, collaboration, creativity, and critical thinking.

The main objective of the study was to develop a Game-Based Approach Courseware in learning Computer System Servicing.

Specifically, the study aimed to:

1. Design and develop a Game-Based Approach Courseware in learning Computer System Servicing.

2. In terms of functionality and acceptability, what is the result of the evaluation of Game-Based Approach Courseware in learning Computer System Servicing?

3. What are the pre-test and post-test performance of the experimental and control group?

3. Is there a significant difference between in the pre-test and post-test performance of the experimental and control group?

\section{RESEARCH METHOD}

Many educators and researchers believe that information technology could bring innovation to traditional educational instructions. Teachers and technologists are searching for new and innovative ways to design learner-centered learning environments effectively, trying to engage learners more in the learning process. The first instrument of structure in creating Game Based Approach Courseware in learning Computer System Servicing is the course syllabus, which outlines the goals and objectives of a course, prerequisites, and the grading/evaluation scheme. The course syllabus is a great place for faculty members to begin helping students appreciate the nature of a game-based approach courseware (William Kearsley 2012). The research applied the Input Process - Output (IPO) to show the development and evaluation process of the Game-Based Courseware in Computer System Servicing.

The Game-Based Courseware come up with the design as an interactive and instructional material for Grade 10 students of Las Piñas East National High School - Equitable Village Annex. The said study will be adopting the ADDIE Model. The ADDIE model provides an excellent skeleton to create Game-Based Courseware in Computer System Servicing. ADDIE Model is a global framework for a more fine-grain design method. In the design phase, ADDIE model will use to ensure that the Game-Based Approach Courseware is design base on clearing learning goals and that it provides students as players with the right information at the right time according to its designs and limitations.

In the evaluation of the developed Game - Based Approach Courseware as interactive material for Grade 10 students, the respondents which are composed of selected TLE teachers and students of Las Piñas East National High School - Equitable Village Annex ask to evaluate the courseware in terms of Functionality that composed of five (5) questions, Usability composed of four (4) questions, Reliability composed of five (5) questions, Performance composed of five (5) questions and Supportability composed of five (5) questions. 


\section{RESULTS AND DISCUSSIONS}

Table 1: Evaluation of Game-Based Approach Courseware in Learning Computer System Servicing

\begin{tabular}{|l|l|l|l|}
\hline \multicolumn{1}{|c|}{ Criteria } & Mean & SD & Interpretation \\
\hline $\begin{array}{l}\text { All information of each lesson is accurate and reliable } \\
\text { relates to the states purpose and goals }\end{array}$ & 4.90 & 0.38 & Excellent \\
\hline Lesson satisfies the teaching content in the course & 4.78 & 0.48 & Excellent \\
\hline Learning outcomes are presented in each lesson & 4.78 & 0.58 & Excellent \\
\hline $\begin{array}{l}\text { Enrichment activities are provided to each lesson to } \\
\text { enhance student's learning. }\end{array}$ & 4.68 & 0.73 & Excellent \\
\hline $\begin{array}{l}\text { Assessment activities are provided to measure the } \\
\text { learning/retention of the students in each lesson. }\end{array}$ & 4.88 & 0.33 & Excellent \\
\hline Overview of the course is provided to orient students & 4.75 & 0.49 & Excellent \\
\hline Average & 4.79 & 0.50 & Excellent \\
\hline
\end{tabular}

It can be gleaned from Table 1 that "All information of each lesson is accurate and reliable relates to the stated purpose and learning goals." got the highest mean of 4.90 and standard deviation of 0.38 and with interpretation of "Excellent". However, the indicator" Assessment activities are provided to measure the learning/retention of the students in each lesson." grabbed the second highest mean of 4.88 and standard deviation of 0.33 and the interpretation of "Excellent"; Learning outcomes are presented in each lesson." had a mean of 4.78 and with the standard deviation of 0.58 with the interpretation of "Excellent". "Lesson satisfies the teaching content in the course outline" has a mean of 4.78 and with the standard deviation of 0.48 and with the interpretation of "Excellent"; "Overview of the course is provided to orient the students in Computer System Servicing." had a mean of 4.75 and with the standard deviation of 0.49 and has the interpretation of "Excellent". The "Enrichment activities are provided to each lesson to enhance students' learning" has a mean of 4.68 and standard deviation of 0.72 and was interpreted as "Excellent". The respondents evaluated the Game - Based Approach Courseware in Learning Computer System Servicing in Instructional content criteria and gave an average mean of 4.79 and with a heterogeneous result in standard deviation of 0.50 where it was interpreted as "Excellent" asshown on Table 1.

\section{CONCLUSION}

Based on the findings on the study the following conclusions were drawn. First, to adopt the opportunities offered by developed game-based courseware, it is essential to focus on lessons learned in Computer System Servicing. Also, features such as peer to peer learning and camaraderie between learners and educators have been found significant in traditional lessons and converted to educational games, as modern technologies move into the informative mainstream. Lastly, Additional research into the effects and development of game-based approach courseware to classify the role of teachers as facilitators in the game-based approach of learning can establish ways to develop and create educational practices that better engage and motivate students. 


\section{Acknowledgement}

Sincere gratitude to our Almighty God for giving the researcher strength, time and knowledge needed to fulfill this endeavor. This is also dedicated to Mavis, Mc Billy, Victor, Madel, Hannah, Hailley and Jeff Beck who are the "wind beneath her wings".

\section{REFERENCES}

Gee, J. P. (2003). What video games have to teach us about learning and literacy. Computers in Entertainment (CIE), 1(1), 20-20.

Heinich, Robert, et al. (2002). "The ASSURE model." Instructional Media and Technologies for Learning. 7th edition. Upper Saddle River, NJ: Merrill/Prentice Hall.

Prensky, M. (2003). Escape from planet Jar-Gon: or what video games have to teach academics about teaching and writing. On the horizon.

Von Wangenheim, C. G., \& Shull, F. (2009). To game or not to game? IEEE software, 26(2), 92-94. 